\title{
Circulating Adipose Stromal Cell
}

National Cancer Institute

\section{Source}

National Cancer Institute. Circulating Adipose Stromal Cell. NCI Thesaurus. Code

C116009.

A precursor of fat-storing cells, which is located in the blood circulation. Detection of these cells is associated with obesity and elevated risk for obesity-related neoplastic diseases such as breast, colon and prostate carcinomas. 